\title{
THE FISHES OF THE CICHLID GENUS CRENICICHLA IN FRENCH GUIANA (PISCES, PERCIFORMES, CICHLIDAE)
}

\author{
by \\ A. PLOEG \\ Institute of Taxonomic Zoology (Zoölogisch Museum), University of Amsterdam, \\ P.O. Box 20125, 1000 HC Amsterdam, The Netherlands
}

\begin{abstract}
A review of the species of the cichlid genus Crenicichla Heckel, 1840 in French Guiana is presented. Five species are encountered, viz.: C. saxatilis (Linnaeus, 1758), $C$. albopunctata Pellegrin, 1904, C. multispinosa Pellegrin, 1903, C. ternetzi Norman, 1926, and C. johanna Heckel, 1840. Their geographic distribution is indicated. The variation of morphometric, meristic, and pigment characters are examined. The variability of these characters is compared with the variability within Crenicichla saxatilis from the Suriname River, Surinam (Ploeg, 1986).

\section{RÉSUMÉ}

On passe en revue les espèces du genre de Cichlidés Crenicichla Heckel, 1840, de Guyane française. Il s'agit de cinq espèces, à savoir: C. saxatilis (Linnaeus, 1758), $C$. albopunctata Pellegrin, 1904, C. multispinosa Pellegrin, 1903, C. ternetzi Norman, 1926, et C. johanna Heckel, 1840. Leur distribution géographique est discutée, ainsi que la variabilité de leurs caractères morphométriques, méristiques et de leur pigmentation. La variabilité de ces caractères est comparée à celle de Crenicichla saxatilis du fleuve Suriname, du Surinam (Ploeg, 1986).
\end{abstract}

\section{INTRODUCTION}

Recently only Le Bail et al. (1984) treated the cichlid genus Crenicichla in French Guiana, although previously much scattered information has been published on this subject (Vaillant, 1900; Pellegrin, 1903, 1904, and 1905; Regan, 1905, 1913; Norman, 1926; Puyo, 1949).

In the past (up to the solution of the FrenchBrazilian border dispute in 1897) French Guiana and the present Brazilian state of Amapa constituted "Guyane française" or "Cayenne" (nowadays the name of the capital and of a river in French Guiana). Formerly the western part of the country was named Mana, which included the area around the Mana River, including the French Guianan border of the Maroni River.

Seven species of Crenicichla have been recorded in the literature as present in French Guiana, viz.: C. brasiliensis (Bloch, 1792); $C$. johanna Heckel, 1840 [including $C . j$. var. carsevennensis Pellegrin, 1905]; C. lugubris Heckel, 1840; C. multispinosa Pellegrin, 1903; C. saxatilis (Linnaeus, 1758) [including $C$. s. var. albopunctata Pellegrin, 1904]; C. ternetzi Norman, 1926; and C. vaillanti Pellegrin, 1904.

For the present study the occurrence of these species in French Guiana is reinvestigated and all type material (except for that of $C$. brasiliensis) has been examined. The variability within the various species has been studied, and is compared with data available from Surinam (Ploeg, 1986, and in prep.). Methods used for counts and measurements are as in Ploeg (1986: 48).

Material of Brazilian tributaries to the Oyapock River, and of Surinam tributaries to the Maroni (= Marowijne) River, is included in order to allow a better understanding about the distribution of the species within this area. The latter material will be treated in a future publication on the Crenicichla species of Surinam.

\section{ACKNOWLEDGEMENTS}

Rich material present in the Institute of Taxonomic Zoology (Zoölogisch Museum) (ZMA), Amsterdam (Dr. H. Nijssen) was used as a basis for the present study. Additional material was made available by the British Museum (Natural History) (BMNH), London (Mrs. B. Brewster), the Institut Royal des Sciences Naturelles de Belgique (ISNB), Brussels (Dr. J. P. Gosse and Mr. L. 
Walschaerts), the Muséum National d'Histoire Naturelle (MNHN), Paris (Dr. M. L. Bauchot and Mr. F. d'Aubenton), the Rijksmuseum van Natuurlijke Historie (RMNH), Leiden (Drs. M. J. P. van Oijen), the Naturhistoriska Riksmuseet (NRM), Stockholm (Dr. S. O. Kullander), the Naturhistorisches Museum (NMW), Vienna (Dr. B. Herzig and Mr. H. Ahnelt), and the Office de la Recherche Scientifique et Technique Outre Mer (ORSTOM), Paris (Dr. P. Y. Le Bail and Mr. P. Planquette). I wish to express my gratitude for their help. Thanks are also due to Mr. J. Zaagman for the drawings, to Mr. L. A. van der Laan for the photographs, to the University of Amsterdam for the facilities, and to Dr. $\mathrm{H}$. Nijssen and Dr. I. J. H. Isbrücker for their criticism and encouragement.

\section{Crenicichla Heckel, 1840}

Crenicichla Heckel, 1840: 416-417 (original diagnosis). Type-species, by subsequent designation of Eigenmann \& Bray, 1894: 620: C. macrophthalma.

Batrachops Heckel, 1840: 432-433 (original diagnosis).

Boggiania Perugia, 1897: 148 (original diagnosis).

Diagnosis. - Elongate; lower jaw somewhat prognathous; orbit in upper half of head; preoperculum serrated. Two well-developed lateral lines with scales larger than adjacent scales, continuing on caudal fin with one or two scales; forehead naked; scales on head, operculum, suboperculum, anterior part of back, and belly cycloid; caudal fin with basal and interradial scales, other fins without basal scales. Dorsal fin acute posteriorly; caudal fin rounded; anal fin origin just below first soft dorsal ray, posteriorly acute, always three anal spines; pelvic fin acute, V I.5; pectoral fin rounded. Teeth conical and recurved, inner teeth series often depressible, outer series fixed. Gill rakers externally on first ceratobranchial denticulate.

\section{KEY TO THE SPECIES OF FRENCH GUIANA}

1a. Scales on sides ctenoid 2

b. Scales on sides cycloid ............ Crenicichla johanna

2a. More than 75 scales below lateral lines; humeral spot absent 3

b. Less than 76 scales below lateral lines; humeral spot present

3a. Caudal fin with dark spot; white dots absent on sides in nuptial males ................. Crenicichla ternetzi

b. Caudal fin without dark spot; white dots present on sides in nuptial males

Crenicichla multispinosa 4a. White dots present on operculum and cheek; humeral spot without notch ........... Crenicichla albopunctata

b. White dots absent on operculum and cheek; humeral spot with notch at dorsoanterior side

Crenicichla saxatilis

\section{Crenicichla saxatilis (Linnaeus, 1758)}

(Figs. 1, 2; table I)

Sparus saxatilis Linnaeus, 1758: 278 (original diagnosis; type-locality: Surinam).

Crenicichla saxatilis; Vaillant, 1900: 125 (Carnot, Carsevenne and Guyane française); Pellegrin, 1904: 373 (Cayenne); Pellegrin, 1905: 589 (Guyane française); Steindachner, 1915: 572 (Maroni River); Puyo, 1949: 243-244 (Mana, Mahury, Oyapock, Montsimery, Cayenne); Ploeg, 1986: 47-59 (Suriname, Marowijne and Commewijne River systems).

Crenicichla saxatilis var. albopunctata Pellegrin, 1904: 374 (in part).

Material. - Surinam and French Guiana:

Marowijne River system: Marowijne River at Tabbetje Hede: ISNB 19567, 8 specimens, 24-XI-1966; Nengre Creek into Marowijne River near Albina: ISNB 19568, 2 specimens, 26-XI-1966; ZMA 119.374 and NRM unreg., Crique Vampire, creek tributary to Marowijne River, St.Laurent du Maroni, 4 specimens, 8-X-1979; ZMA 119.733, Crique Cascade, creek tributary to Canal St.Jean (Maroni) near St.-Jean, 2 specimens, 21-I-1980; ZMA 119.373 and NRM unreg., Crique Balaté, 5 specimens, 9-X-1979.

Mana River system: ZMA 119.376, Crique St.-Anne, 1 specimen, 22-IX-1978.

Counamama River system: ZMA 119.377, Pri-Pri YiYi, along the Route National 1, between Corossony and Iracoubo, 2 specimens, VII-1983.

Sinnamary River system: ZMA 119.380, Bayou, lower Sinnamary River, upstream of village Sinnamary, 1 specimen, VI-1981; ZMA 119.381, Petit Saut, Sinnamary River, at the level of Crique Coeur-Maroni, 1 specimen, 3-II-1983.

Kourou River system: ZMA 119.378, Crique Papinabo, creek tributary to Kourou River, 1 specimen, 24-I-1983.

Mahury River system: ZMA 119.372 and NRM unreg., Crique Blanche, creek tributary to Orapu River, 2 specimens, 3-X-1979; ZMA 119.375 and NRM unreg., Crique Gabrielle, creek tributary to Mahury River upstream of Roura River, 8 specimens, 5-X-1978; ZMA 119.379, Crique Magnan, creek tributary to Comté River, 1 specimen, 5-X-1978.

Approuague River system: ZMA 111.255, Kaw Guisanbourg, near outlet of Approuague River, 1 specimen, VIII-1971.

Oyapock River system: ZMA 107.845 , Brazil, state of Amapa, Igarape Jumina, Savanna Creek at Youminan $\left(04^{\circ} 03^{\prime} \mathrm{N} 51^{\circ} 39^{\prime} \mathrm{W}\right), 1$ specimen, 20-IX-1977; ZMA 


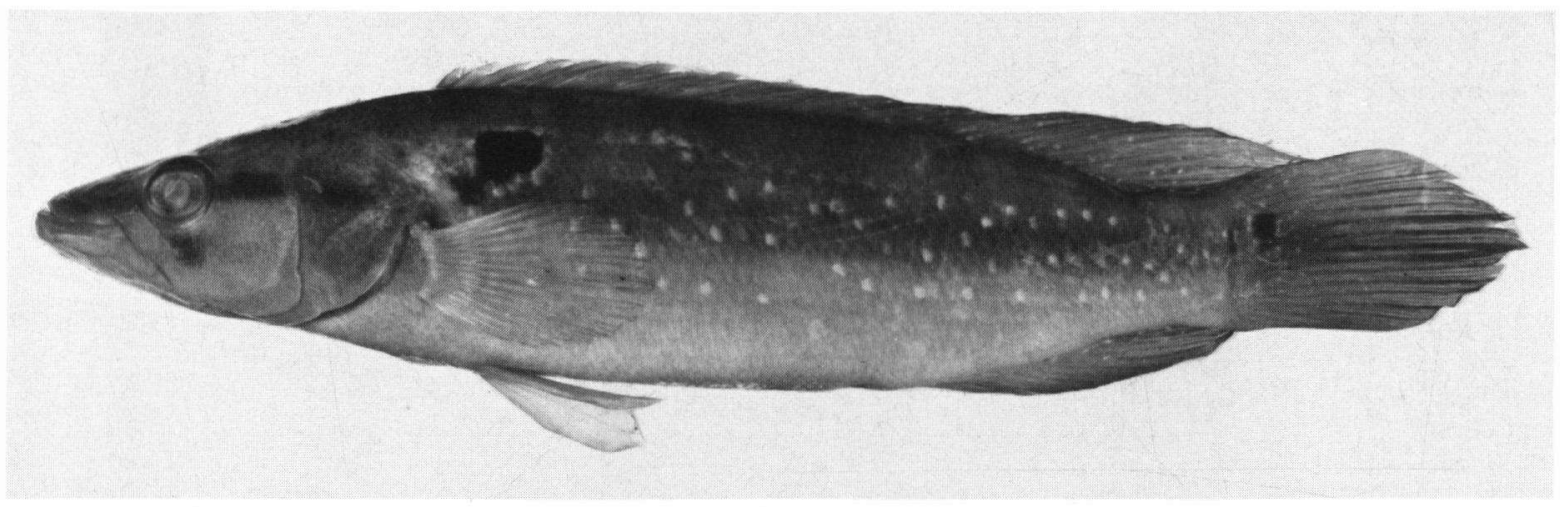

Fig. 1. Crenicichla saxatilis (Linnaeus, 1758) from the Oyapock River, Gabaret Creek, ZMA 107.644, $167 \mathrm{~mm}$ SL, male.

107.644, Gabaret Creek near its confluence with Oyapock River, 1 specimen, 11/14-XI-1976; ZMA 107.697, Saut Maripa and downstream of Pied Saut, falls in Oyapock River, 1 specimen, 5-XI-1976; ISNB 20.084, Camopi River, 1 specimen, 30-XI-1969; ISNB 20.085, Alikene Creek, right creek tributary to Camopi River, 5 specimens, 1-XII-1969; ISNB 20.086, Adjoumba Creek, between Sikini and Camopi, right creek tributary to Oyapock River, 7 specimens, 6-XII-1969; ZMA 107.734, Euleupousing Creek near its confluence with Oyapock River, 1 specimen, 6-X-1967; ZMA 107.728, Mare Ipa near Trois Sauts in upper Oyapock River, 3 specimens, 8-X-1967.

Notes. - For a detailed description of Crenicichla saxatilis see Ploeg (1986), concerning C. saxatilis from its restricted type-locality: Surinam, Carolina Creek, Suriname River system.

In Surinam and French Guiana $C$. saxatilis occurs in the rivers of and between the Suriname and Oyapock River systems. In these rivers the species exhibits a considerable variability in colour pattern, not only between the rivers, but also within one river. Puyo (1949: 243-244) pointed out that variation in colour is influenced by different habitats: "la coloration de l'eau (boueuse, claire, verdâtre, etc.)"'. Morphometric and meristic variability can be explained in particular by the influence of different water temperatures and currents (Ploeg, 1986: 57). Specimens from French Guiana differ from those of the Carolina Creek (topotypes) in: (a) having occasionally a less conspicuous humeral spot (always present in topotypes), (b) 10 or more gill rakers (8-9 in topotypes), and (c) 3 teeth series or less in the lateral part of the upper jaw in adults, and 2 teeth series in the lateral part of the lower jaw (up to 5 and up to 4 teeth series, respectively, in adult topotypes).

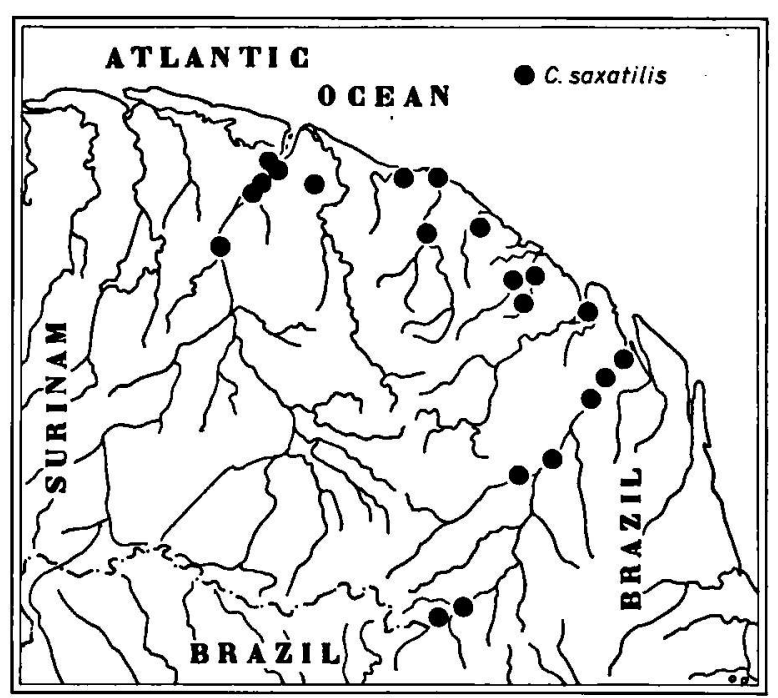

Fig. 2. Distribution of Crenicichla saxatilis (Linnaeus, 1758). Single dots may represent more than one sample.

Variability within one river could not be observed (as found in the Suriname River (Ploeg, 1986: 56)), because in French Guiana C. saxatilis is not known from both lower and upper parts of the same river (except for the Oyapock River, from which however no series larger than one to three specimens were available, showing no noteworthy intraspecific 
TABLE I

Morphometric and meristic data of $C$. saxatilis, C. albopunctata, C. johanna, C. ternetzi, and C. multispinosa. Data marked with * are based on the lectotype and two paralectotypes only (MNHN A 9497).

\begin{tabular}{|c|c|c|c|c|c|}
\hline Species & C. saxatilis & C. albopunctata & C. johanna & C. ternetzi & C. multispinosa \\
\hline Number of specimens & 25 & 25 & 25 & 25 & 11 \\
\hline Total length (mm) & $46-149$ & $98-169$ & $66-283$ & $57-245$ & $124-266$ \\
\hline Standard length (mm) & $37-121$ & $78-139$ & $53-235$ & $47-203$ & $104-225$ \\
\hline Head length (\% SL) & $31-36$ & $32-35$ & $29-34$ & $30-38$ & $32-34$ \\
\hline Head depth (\% SL) & $15-24$ & $18-23$ & $17-21$ & $14-18$ & $14-16$ \\
\hline Head width (\% SL) & $12-16$ & $12-14$ & 14-18 & $11-16$ & $13-15$ \\
\hline \multicolumn{6}{|l|}{ Depth caudal peduncle } \\
\hline$(\% \mathrm{SL})$ & $11-14$ & $10-12$ & $10-12$ & $10-12$ & $10-12$ \\
\hline \multicolumn{6}{|l|}{ Length caudal peduncle } \\
\hline$(\% \mathrm{SL})$ & $10-14$ & $8-11$ & $10-13$ & $11-14$ & $11-12^{*}$ \\
\hline Snout length (\% SL) & $8-10$ & $9-12$ & 8-11 & $8-13$ & $11-14$ \\
\hline Upper jaw length (\% SL) & $9-14$ & $10-14$ & $10-12$ & 8-13 & $9^{*}$ \\
\hline Lower jaw length (\% SL) & $14-18$ & $15-19$ & $14-17$ & $10-16$ & $13-14^{*}$ \\
\hline \multicolumn{6}{|l|}{ Length last dorsal spine } \\
\hline$(\% \mathrm{SL})$ & $9-13$ & $10-12$ & $9-11$ & $7-10$ & $8-9 *$ \\
\hline Orbital diameter (\% HL) & $19-29$ & $20-25$ & $16-22$ & $15-26$ & $15-20$ \\
\hline Width of interorbital (\% HL) & $21-35$ & $15-24$ & $27-38$ & $20-30$ & $20-29$ \\
\hline Scales first lateral line & $21-25$ & $22-25$ & $24-28$ & $26-28$ & $26-29$ \\
\hline Scales second lateral line & $8-13$ & 8-11 & $13-15$ & $11-14$ & $12-15$ \\
\hline Scales below lateral lines & $52-68$ & $57-65$ & $110-125$ & $90-100$ & $98-110$ \\
\hline Number of dorsal spines & $15-20$ & $17-21$ & $20-22$ & $23-25$ & $23-25$ \\
\hline Number of soft dorsal rays & $13-15$ & $11-15$ & $16-19$ & $13-15$ & $13-15$ \\
\hline Number of soft anal rays & $8-11$ & $9-11$ & $11-13$ & $9-11$ & $9-10$ \\
\hline Material included & $\begin{array}{c}\text { ZMA 111.255; } \\
\text { ISNB } 20.086\end{array}$ & $\begin{array}{c}\text { ZMA } 107.839 \\
107.840 \\
106.509\end{array}$ & $\begin{array}{c}\text { ZMA 107.658; } \\
\text { ISNB 15.868, } \\
\text { 20.069, 20.070; } \\
\text { MNHN } 1899.113 \\
1981.539\end{array}$ & $\begin{array}{c}\text { ISNB } 15.885 \\
15.887,20.089 \\
20.091,20.114\end{array}$ & $\begin{array}{c}\text { RMNH } 18.961 ; \\
\text { MNHN A } 9497 \text {, } \\
9542\end{array}$ \\
\hline
\end{tabular}

variability). In the upper Maroni River C. saxatilis is not found; from the Mana and Sinnamary River systems no material is available from upper regions.

Oyapock River specimens show a slightly different pattern of dots on the sides in adult males: fewer and somewhat larger. The humeral spot has the notch more ventrad than in specimens from the Suriname River.

Crenicichla albopunctata Pellegrin, 1904 (Figs. 3-5; table I)

Crenicichla saxatilis var. albopunctata Pellegrin, 1904: 374 (original description). Syntype-localities: Guyane anglaise, Surinam, Guyane française.
Material.- Lectotype, by present designation: MNHN 98-59, $149 \mathrm{~mm}$ SL male, Guyane française.

Surinam and French Guiana:

Maroni River system: ZMA 107.839, Lawa River, Maka Creek, $10 \mathrm{~km}$ south of Stoelmans Island, 1 specimen, 21-IV-1966; ZMA 107.840, Lawa River, Maka Creek, $10 \mathrm{~km}$ south of Stoelmans Island, 1 specimen, 21-IV-1966; ZMA 106.507, right bank tributary to Marowijne River, east to Mooisantitabbetje, $36 \mathrm{~km}$ north of Stoelmans Island, 12 specimens, 19-IV1967; ZMA 106.508, left bank tributary of Marowijne River, west to Manbarie fall, $6 \mathrm{~km}$ north of Stoelmans Island, 19 specimens, 20-IV-1967; ZMA 106.509, Lawa River, Maka Creek, $10 \mathrm{~km}$ south of Stoelmans Island, 53 specimens, 21-IV-1966; ZMA 106.510, Soea kisi Creek, left bank tributary to Tapanahony River, $12 \mathrm{~km}$ southwest of Stoelmans Island, 49 specimens, 22-IV-1967; ZMA 106.511, Kamaloea, right bank tributary to Marowijne River, $9 \mathrm{~km}$ southeast of mouth of Gran 


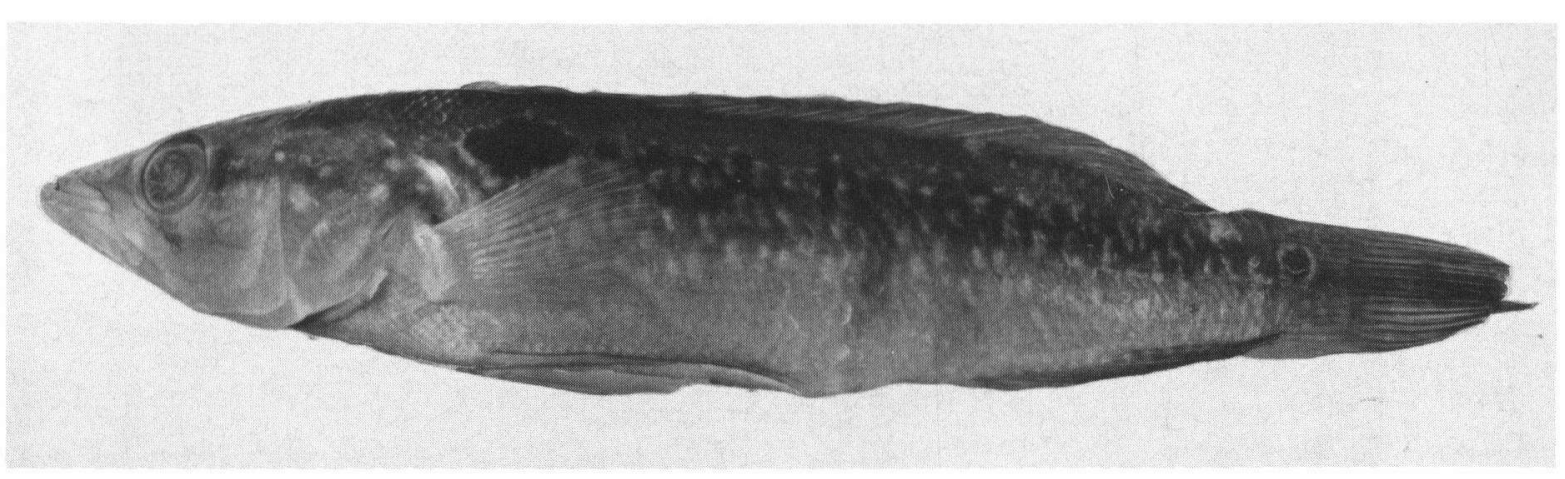

Fig. 3. Crenicichla albopunctata Pellegrin, 1904 from French Guiana, lectotype MNHN 98-59, 149 mm SL, male.

Creek, 35 specimens, 24-IV-1967; ISNB 20816, Lawa River, Maripasoela, Daouda Creek near airstrip, 3 specimens, 12-XI-1969; ISNB 20817, Inini River, Saut Sonelle, 3 specimens, 16-XI-1969; ISNB 20818, Bois Blanc Creek, right bank creek tributary to Inini River, 5 specimens, 16-XI-1969; ISNB 20819, Quaqui River, right bank tributary to Tampoc River, Saut Bali, 3 specimens, 18-XI-1969; ISNB 20820, Quaqui River, upstream of Saut Bali, 5 specimens, 18-XI-1969; ISNB 20821, rapids in Paloemeu River, upstream of confluence with Walimeroe Creek, 1 specimen, 3-XI-1966; ISNB 20822, right bank tributary to Marowijne River near Tabbetje Hede, 6 specimens, 24-XI-1966; ISNB 20823, small brooklet in upper Oelemari River, 3 specimens, 13-XI1966; ISNB 20824, small brooklet in upper Oelemari River, 5 specimens, 14-XI-1966; ISNB 20825, Paloemeu River at Papadronsoela, 2 specimens, 1-XI-1966; ISNB 20826, right bank tributary to Paloemeu River between Trombeka-North and Trombeka-South, 2 specimens, 8XI-1966; ISNB 20827, right bank tributary to Tapanahony River, downstream of confluence with Paloemeu River, near Paloemeu airstrip, 3 specimens, 9XI-1966; ISNB 20828, right bank tributary to Oelemari River near Oelemari airstrip, 15 specimens, 10-XI-1966; ISNB 18966, Oelemari near airstrip, 5 specimens, no date; ISNB 20829, small brooklet in upper Oelemari River, 3 specimens, 14-XI-1966; ISNB 20830, rapids in Oelemari River near Oelemari airstrip, 6 specimens, 15XI-1966; ISNB 20831, tributary to Lawa River near Anapaïkekondre, 4 specimens, 28-XI-1966; ISNB 18959, Paloemeu near Walimeroe Creek, 1 specimen, no date; ISNB 19567, Marowijne River near Tabbetje Hede, 5 specimens, no date; ZMA 119.385 and NRM unreg., Crique Cascade, creek tributary to Canal St.-Jean, 2 specimens, 21-I-1980.

Mana River system: ZMA 119.384 and NRM unreg., Sub-Acarouany, creek tributary to lower Mana River, opposite to village Acarouany, 3 specimens, 3-III-1980.

Approuague River system: ZMA 119.383 and NRM unreg., Approuague basin, 4 specimens, IV-1983.
Mahury River system: ZMA 119.386, Crique Gabrielle, creek tributary to Mahury River upstream of Roura, 1 specimen, 5-X-1978.

Notes. - A detailed description of Crenicichla albopunctata will be included in a future article on the Crenicichla species of Surinam.

The syntype-localities "Guyane anglaise, Surinam, Guyane française" cover an area far larger than the distribution of the species recorded above. Therefore, the type-locality needs to be restricted. Because of the impossibility to determine from where the lectotype originated, I herewith restrict the typelocality arbitrarily to the Maroni River system, Lawa River, Maka Creek, $10 \mathrm{~km} \mathrm{S.} \mathrm{of}$ Stoelmans Island (ZMA 106.509, 119.839, 119.840: a large series of well-preserved specimens).

The five syntypes of $C$. saxatilis var. albopunctata represent at least two species. Only one of the specimens, MNHN 98-59, represents the species described here as $C$. albopunctata, and therefore is designated the lectotype. Paralectotype MNHN A-9502 can be identified as C. saxatilis by the shape of its humeral spot (a notch at the dorsoanterior side). Paralectotype MNHN 4083 is probably also C. saxatilis, because of its origin "Surinam" (most likely originating from the Suriname River; in this river no other $C$. saxatilis-like species occur). Unfortunately, its colour pattern is faded. Paralectotypes MNHN A-9498 are two specimens from (British) Guiana. One of the 


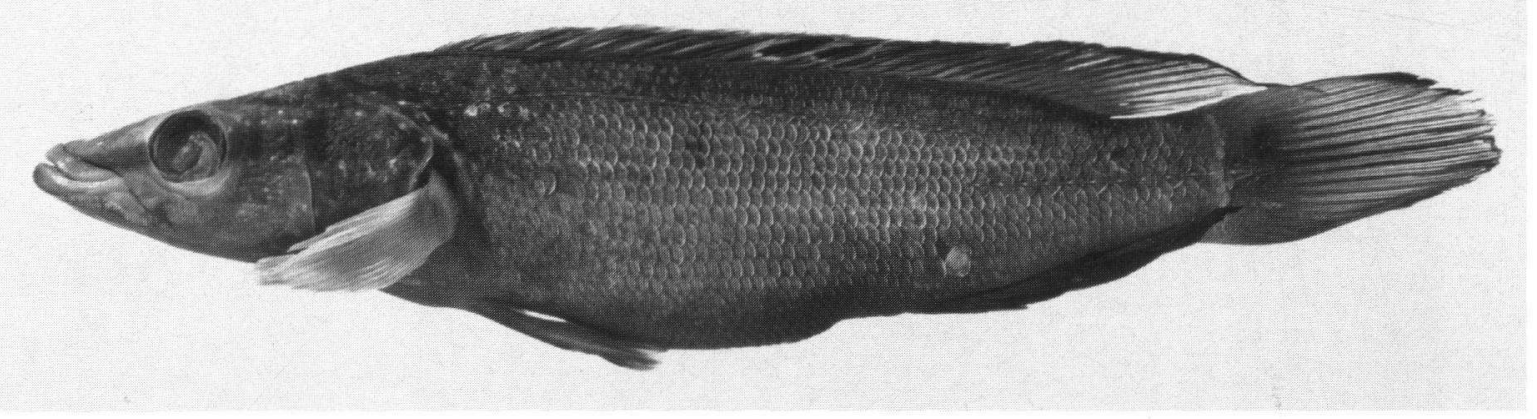

Fig. 4. Crenicichla albopunctata Pellegrin, 1904 from the type-locality, ZMA 107.840, $124 \mathrm{~mm}$ SL, female.

two shows a humeral spot as in $C$. saxatilis, the other is faded.

The syntype of $C$. vaillanti (MNHN 4050) originates from French Guiana: "Mana". It is a bleached specimen. Morphometric and meristic data agree with both $C$. saxatilis and $C$. albopunctata. Morphometric and meristic data are reminiscent mostly of $C$. albopunctata, but do not exclude synonymy with $C$. saxatilis. For the moment I consider the French Guiana syntype to be conspecific with $C$. albopunctata. The second syntype, MNHN 2993, from the Essequibo River, needs comparison with Crenicichla specimens from the Essequibo River.

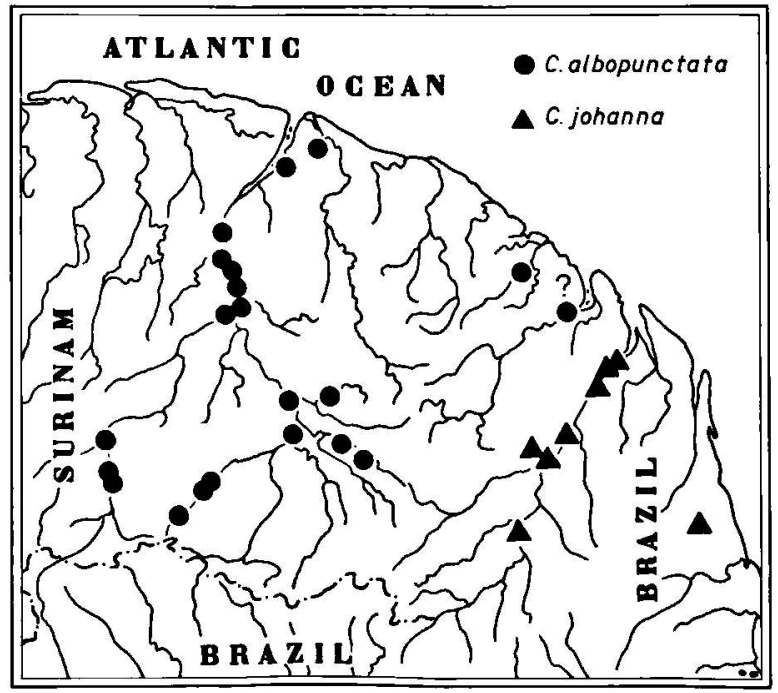

Fig. 5. Distribution of Crenicichla albopunctata Pellegrin, 1904 and Crenicichla johanna Heckel, 1840. Single dots may represent more than one sample.
Crenicichla johanna Heckel, 1840

(Figs. 5, 6; table I)

Crenicichla johanna Heckel, 1840: 425-426 (original descrip. tion), type-locality: Guaporé River.

C. johanna; Regan, 1913: 504 (name only); Le Bail et al., 1984: 43 (Guyane française).

Crenicichla brasiliensis var. vittata (non Heckel, 1840); Pellegrin, 1904: 383 (Carsevenne (Guyane française)).

Crenicichla johanna var. carsevennensis Pellegrin, 1905: 168169 (original description of this variety). Entre les rivières Carsevenne et Cachipour (contesté francobrésilien).

Material. - French Guiana and Brazil:

Oyapock River system: ZMA 107.658, Suivelaleu Creek near its confluence with upper Oyapock River $\left(02^{\circ} 40^{\prime} \mathrm{N} 52^{\circ} 33^{\prime} \mathrm{W}\right), 1$ specimen, $13-\mathrm{X}-1976$; ISNB 15.868, Igarapé Cumuri, left bank of tributary to Oyapock River, upstream of first rapids of Grande Roche, 2 specimens, 5-XII-1962; ISNB 15.869, Igarapé Taparabu, right creek tributary to Oyapock River, downstream of St.-Georges, 3 specimens, 8-XII-1962; ISNB 20.069, Crique Alikene, left creek tributary to Camopi River, 3 specimens, 1-XII-1969; ISNB 20.070, Crique Sikini, left creek tributary to Oyapock River, 1 specimen, 6-XII-1969; MNHN 01-461, Camopi River, 1 specimen; MNHN 1981-539, Crique Gabaret, 1 specimen.

Calçoene River system: MNHN 1899.113, Calçoene River, 1 specimen (paratype of $C$. johanna var. carsevennensis).

Description. - Body behind head laterally compressed; head somewhat flattened; predorsal contour straight, preventral contour convex; angle between predorsal and preventral contour about $35^{\circ}$; snout blunt, both in lateral aspect and from above; lips thick; mouth wider than interorbital; orbit in upper half of head, orbital 
diameter about $1 / 3$ of head depth at orbit level; nostrils nearer to postlabial skinfold than to orbit, distance between nostrils and orbit about as long as orbital diameter; maxilla reaching to anterior margin of orbit.

Scales cycloid; some scales on anterior part of body fused in vertical direction; number of scales below lateral lines (in 13 specimens): 110 (2), 111 (1), 112 (3), 113 (1), 115 (1), 117 (1), 118 (2), 119 (1), 125 (1); number of scales in lateral lines: 24/13 (1), 24/15 (1), 25/15 (2), 26/13 (1), 26/14 (3), 27/13 (2), 27/14 (1), 28/13 (2); 5-6 horizontal scale series between the lateral lines; lateral line continuing on caudal fin with one or two scales; interradial scales 1/3$2 / 3$ of caudal fin length.

In lateral part of mouth two teeth series in both jaws; teeth of outer series largest and fixed, inner teeth series depressible. Externally on first ceratobranchial 9-12 rakers.

Dorsal fin origin just dorsal to pectoral fin; spines increasing in length to about tenth; soft part of dorsal fin acute, fifth ray from last the longest, reaching to just behind caudal fin base; D XX.18 (2), XX.19 (1), XXI.17 (3), XXI.18 (2), XXII.16 (2), XXII.17 (3). Caudal fin rounded; about $23 \%$ of SL. Anal fin acute, third ray from posterior the longest; spines thick; A III.10 (1), III.11 (3), III.12 (7), III.13 (2). Ventral fin acute, first soft ray the longest, and reaching only to one third of the distance to anal fin origin; spine less than half as long as first soft ray. Pectoral fin rounded; about 1.5 times as long as ventral fin.
Colour pattern. - No sexual dimorphism in colour pattern found. Ground colour of body brown, countershaded. Dorsal, pectoral, pelvic, and anal fins light. From tip of snout to end of caudal fin a dark brown band, about $1 / 4$ of body depth, covers the body, running below upper lateral line and through lower lateral line. In the caudal fin this band is rather faint. Just below dorsal spines a second, lighter brown lateral band is present. More conspicuous in this area and more caudad, are about 12 dark vertical bars between dorsal fin and upper lateral line. Small brown dots, forming dark lines, are present on dorsum of head. The caudal fin shows a vague lateral band in the middle, and two light bands, forming a $\mathrm{V}$ with the open end directed anteriad and the point directed backwards. Anal fin with distinct dark margin. Neither humeral spot, nor spot on caudal fin present.

Notes. - Unfortunately, the holotype of $C$. johanna (NMW 16.431) was not available due to the current policy of the Vienna Museum. Mr. Ahnelt kindly provided me with a good photograph of this specimen.

The label of the Crenicichla specimen with register no. MNHN 1899-113 indicates that it is the holotype of $C$. johanna var. carsevennensis, which is not true. This specimen was recorded by Pellegrin (1904: 383) as $C$. brasiliensis var. vittata. According to the original description of C. johanna var. carsevennensis, in which only one specimen was mentioned, the holotype of this

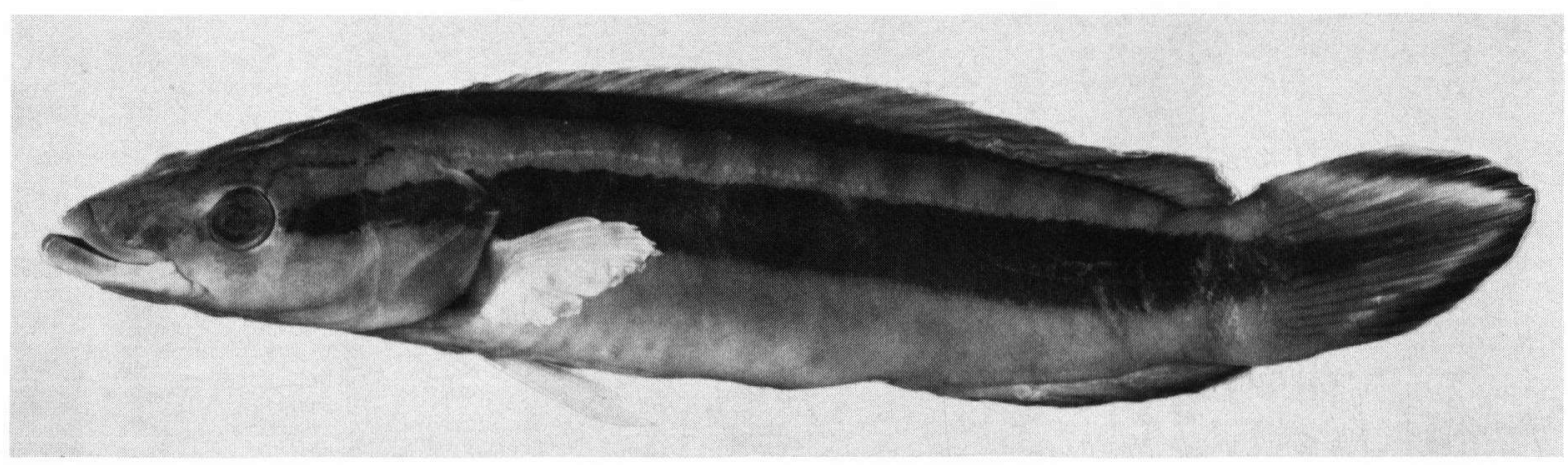

Fig. 6. Crenicichla johanna Heckel, 1840, paratype of C. j. var. carsevennensis Pellegrin, 1904 from the Calçoene River MNHN 1899.113, $175 \mathrm{~mm}$ SL, sex unknown. 
subspecies is a specimen with register no. MNHN 1899-112. The type-locality of the variety is "Entre les rivières Carsevenne et Cachipour (contesté franco-brésilien)". The Carsevenne River is nowadays named Calçoene River; Cachipour is presently written Caciporé.

The distribution of $C$. johanna in the Guianas is interesting. The species occurs in the Oyapock, Amazon, Branco, and in the Essequibo River systems. Its distribution surrounds the centre of the Guianas from the Corantijne basin to the Approuague system, from where the species is not known. According to LoweMcConnell (1964: 105) the Essequibo River and Branco River systems are in contact (through the Rupununi and Tacutu River) during the rainy season in wet years by flooded areas. A similar situation exists between branches of the Oyapock River and branches of the Jari River systems and can explain the presence of $C$. johanna in these systems.

In the material studied the number of scales below the lateral lines is compared with the original description. Heckel mentioned 98 scales, whereas I found 110-125. This can be due to the way of counting, but also to intraspecific variation (Heckel's specimens came from the Rio Guaporé in western Brazil).

A specimen labeled as "paratype" (there are no paratypes) of $C$. johanna present in the collection of Vienna (NMW 77.770) is a C. vittata.

\section{Crenicichla ternetzi Norman, 1926}

(Figs. 7, 8; table I)

Crenicichla ternetzi Norman, 1926: 97 (original description). French Guiana: Oyapock River, Sant Cafesoca; Le Bail et al., 1984: 43 (Guyane française).

Material - - Lectotype, by present designation, BMNH 1926.3.2:860, $163 \mathrm{~mm}$ SL, male, French Guiana: Oyapock River, Sant [= Saut] Cafesoca. Paralectotype: BMNH 1926.3.2:861, $161 \mathrm{~mm}$ SL male, same data as lectotype.

French Guiana and Brazil:

Oyapock River system: ISNB 15886, creek tributary to brooklet left of Igarapé Ciparini, tributary to Oyapock River upstream of Clevelandia, State of Amapa, 2 specimens, 4-XII-1962; ISNB 15887, French Guiana:
Igarapé Cumuri, brooklet left of Oyapock River, upstream of first rapids of Grande Roche, 3 specimens, 5XII-1962; ISNB 19.678, Camopi River, Pauwé Jean-Jean (downstream of Saut Mauvais), 1 specimen, 30-XI-1969; ISNB 20.089, Camopi River, Pauwé Jean-Jean (downstream of Saut Mauvais), 9 specimens, 30-XI-1969; ISNB 20.090, Crique Alikene, left creek tributary to Camopi River, 6 specimens, 1-XII-1969; ISNB 20.091, Saut Alikote (upstream of Camopi village), 122 specimens, 4-XII-1969; ISNB 10.114, upstream of St. Kumalawa, upstream of Camopi village, 1 specimen, 27VII-1982; MNHN 01-462, Camopi River, 1 specimen, no date.

Description. - Based on lectotype and 15 other specimens (ISNB 20.091). Very elongate, slightly laterally compressed; head more or less depressed; predorsal contour either slightly convex or straight; preventral contour straight; angle between preventral and predorsal contour about $35^{\circ}$; snout pointed from the side, blunt from above; mouth as wide as interorbital diameter; maxilla not reaching anterior edge of orbit; nostrils halfway between orbit and postlabial fold of skin; orbital diameter about half head depth at orbit level; orbit in upper half of head; caudal peduncle about as deep as long.

Occasionally with ctenoid scales just behind pectoral fin; scales on body becoming larger posteriorly; lectotype with 93 scales below lateral lines, in 13 other specimens 90, 94 (4), 95 (3), 96 (2), 97, 99, 100; lectotype with $27 / 12$ scales in lateral lines, in 15 other specimens: 26/12, 26/13 (4), 26/14 (2), 27/12, 27/13 (5), 28/11 (2); lateral line scales 3 or 4 times larger than adjacent scales; $3-4$ scales in horizontal series between lateral lines; lateral line continuing onto caudal fin with 2 scales; 3-4 basal scale series on caudal fin; interradial scales reaching to half caudal fin length.

Dorsal fin origin just behind upper edge of operculum; spines increasing in length to about seventh, remaining spines equal in length; soft part posteriorly acute, sixth ray from last the longest, reaching to half caudal fin length; lectotype: D XXIII.13, in 15 other specimens: XXIII.13, XXIII.15, XXIV.13, XXIV.14 (12). Caudal fin rounded, $17-22 \%$ of SL. Anal fin posteriorly acute, fourth ray from last the 


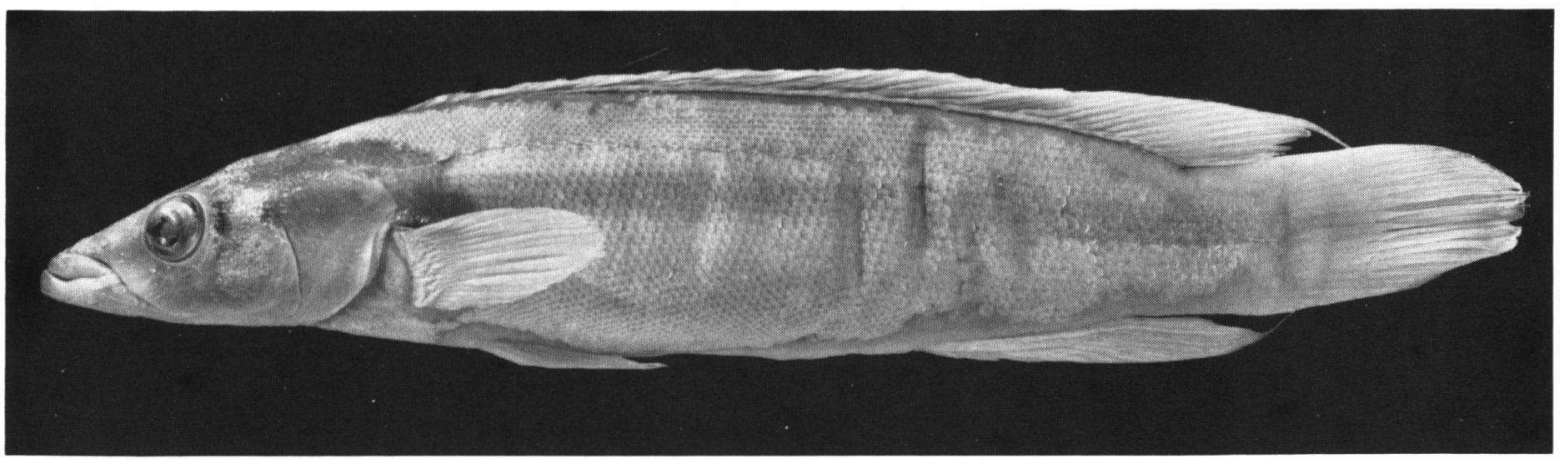

Fig. 7. Crenicichla ternetzi Norman, 1926 from the Oyapock River at Saut Cafesoca, lectotype BMNH 1926.3.2:860, 163 mm SL, male.

longest, in males reaching to halfway the caudal fin length, in females to just behind base of caudal fin; lectotype: A III.9, in 15 other specimens: III.9 (2), III.10 (13). Ventral fin acute; spine half as long as first soft ray; second soft ray longest, little shorter than caudal fin. Pectoral fin little longer than ventral fin, rounded.

Externally on first ceratobranchial 11 to 12 gill rakers; dorsal four or five rakers boomerang-shaped, remaining ones knobshaped.

Colour pattern. - The lectotype is dull grey with only a dark lateral band. The description of the colour pattern is based on fresh material (ISNB 20.091).

Ground colour brown; back dark brown, a still darker lateral band, ventral part of body yellow-brown to yellow; lateral band running from distal tip of lower jaw, below nostril, over orbit and gill cover, below first lateral line, on and above second lateral line, to end of caudal fin, where it gradually becomes faint; vague, dark suborbital stripe in males, several vague darker suborbital blotches in females; no dots on body; dorsal fin in males grey with dark margin, grey part posteriorly with faint light dots; females with grey dorsal fin without dots, with narrow dark margin, thin white edge basally of this margin; caudal fin of males grey with vague white dots, females without these dots; caudal fin with two white bands forming a V with the open end directed anteriad; males with some vague light dots in posterior three soft rays; ventral fin yellowish; pectoral fin grey; juveniles (SL less than about $50 \mathrm{~mm}$ ) yellow with dark brown horizontal band from snout to end of caudal fin rays; a second horizontal dark band on base of dorsal fin, continuing on the head between the eyes; a short horizontal dark stripe, from dorsal part of orbit to edge of operculum.

Notes. - Crenicichla ternetzi is reminiscent of C. multispinosa. However, C. multispinosa can easily be distinguished from $C$. ternetzi by its colour pattern: (a) many white dots in males of $C$.

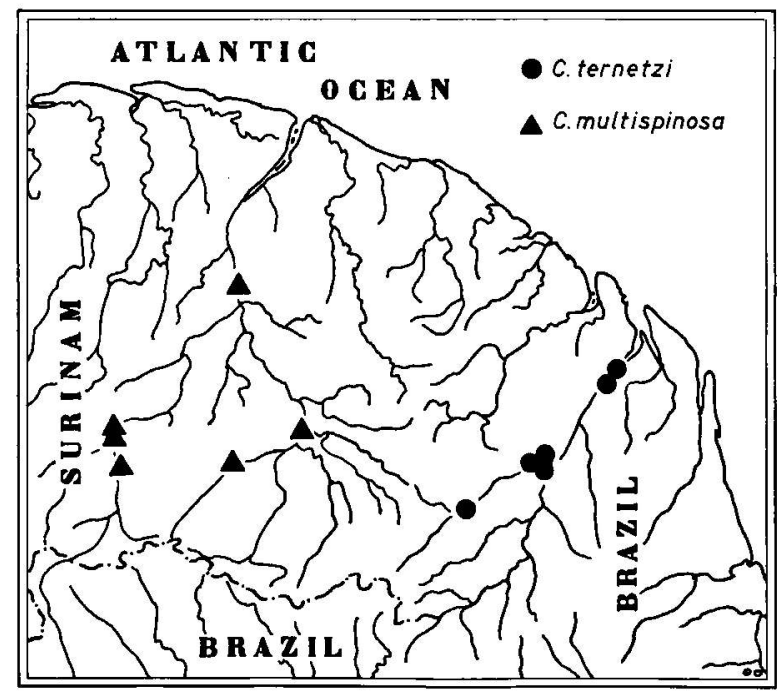

Fig. 8. Distribution of Crenicichla ternetzi Norman, 1926, and Crenicichla multispinosa Pellegrin, 1903. Single dots may represent more than one sample. 
multispinosa (absent in C. ternetzi), (b) presence of a caudal fin spot in C. multispinosa (absent in C. ternetzi), (c) white bands in the caudal fin of C. 'ternetzi females (absent in C. multispinosa). Another distinguishing character is the number of scales below the lateral lines (on the average eight more in C. multispinosa). However, this character is of less value because of the known intraspecific variability in some Crenicichla spp. (cf. Ploeg, 1986). C. multispinosa and C. ternetzi do not occur sympatrically.

The resemblance of the colour pattern of adult $C$. ternetzi and juvenile $C$. johanna is remarkable. Both species occur sympatrically.

\section{Crenicichla multispinosa Pellegrin, 1903}

(Figs. 8, 9; table I)

Crenicichla multispinosa Pellegrin, 1903: 124 (original description), Guyane française; Pellegrin, 1904: 380-381 (Guyane française, Surinam); Le Bail et al., 1984: 44 (Guyane française).

Crenicichla lugubris (not Heckel, 1840); Nijssen, 1967: 246 (Surinam: Lake Brokopondo); Richter \& Nijssen, 1980: 125 (Surinam, Lake Brokopondo).

Material.- Lectotype, by present designation, MNHN 9542, 137 mm SL, French Guiana. Paralectotypes: MNHN 9542, 2 specimens, French Guiana; MNHN 9496, 3 specimens, French Guiana.

Surinam and French Guiana:

Marowijne River system: ISNB 18958, Paloemeu River, Papadronsoela, 1 specimen, 1-XI-1966; ISNB 18959, Paloemeu River, Waloemeroe Creek, 38 specimens, 3-II-1966; ISNB 18960, Oelemari River near airstrip, 2 specimens, 15-XI-1966; RMNH unreg., Tapanahony River, $2 \mathrm{~km}$ downstream of airstrip, 14 specimens, 17-XI-1965; RMNH unreg., Tapanahony River, $2.5 \mathrm{~km}$ downstream of airstrip, 5 specimens, 30XI-1965; RMNH 28975, Tapanahony River, 2 km below mouth of Paloemeu River, 1 specimen, 16/17-I-1964; ISNB 18961, Lawa River, Anapaïkekondre, 26 specimens, 18-XI-1966; ZMA 106.511, Kamaloea or Saloea Creek, $9 \mathrm{~km}$ south of Gran Creek, 35 specimens, 24-IV-1967; ZMA 100.735, Marowijne River, 2 specimens, 1952.

Notes. - A detailed description of Crenicichla multispinosa will be included in a future article on the Crenicichla species of Surinam.

Dots on posterior part of body present only in nuptial males, collected during the short rainy season: December-February.

C. multispinosa seems to be restricted to the Suriname and Maroni (Marowijne) River systems. In these systems the species is collected in the upper regions only.

The original type-locality (Guyane française) is poorly defined since the species is present in a small part of the country only. Therefore, I herewith restrict the type-locality to the Maroni River, South of Gran Creek (based on material listed above).

C. multispinosa and C. ternetzi are more similar to each other than both are to other Crenicichla species. The very elongate body shape, more or less depressed head, maxilla not reaching anterior edge of orbit, small scales, pointed snout, many dorsal spines, and the nostrils placed just between orbit and postlabial skinfold, distinguish these two species from the remaining species of the genus.

SPECIES ERRONEOUSLY RECORDED FROM FRENCH GUIANA

Crenicichla brasiliensis (Bloch, 1792). Pellegrin, 1904: 381 used the name $C$.

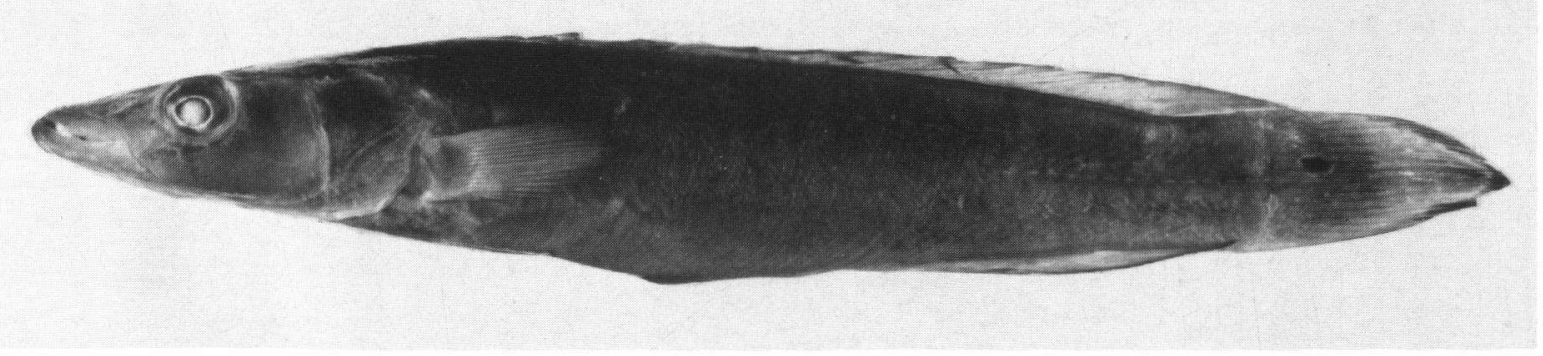

Fig. 9. Crenicichla multispinosa Pellegrin, 1903 from French Guiana, lectotype MNHN 9542, 137 mm SL, male. 
brasiliensis for $C$. $b$. var. johanna and $C . b$. var. lugubris, which he regarded varieties of the same species. Specimens from the MNHN collection labelled $C$. brasiliensis are re-identified as $C$. johanna (MNHN 01-461) and C. ternetzi (MNHN 01-462).

Crenicichla lugubris Heckel, 1840. - The record of Le Bail et al., 1984 is based on a misidentification (Richter \& Nijssen, 1980 misidentified C. multispinosa as C. lugubris).

\section{DISCUSSION}

Although many rivers in French Guiana are scarcely sampled, there are striking differences between the Maroni River system (with $C$. albopunctata and $C$. multispinosa), and the Oyapock River system (with $C$. ternetzi and $C$. johanna). The two river systems share one species only: $C$. saxatilis. Most rivers between these two border rivers (Mana, Iracoubo, Sinnamary, Kourou, Cayenne, and Orapu) show an influence of the Maroni River by the occurrence of $C$. albopunctata. The Oyapock River system, however, has its own Crenicichla species together with some influence of the Amazon basin (C. johanna).

\section{REFERENCES}

Bail, P. Y. Le, P. Planguettr \& J. Géry, 1984. Clé de détermination des poissons continentaux et côtiers de Guyane, IV. Espèces dulcaquicoles non Siluriformes. Bull. Liaison Inst. natn. Rech. agron. Lab. Hydrobiol., Kourou, 9: 1-97.

Eigenmann, C. H. \& W. L. Bray, 1894. A revision of the American Cichlidae. Ann. New York Acad. Sci., 7: 607-624.

Heckel, J., 1840. Johan Natterer's neue Flussfische Brasilien's, nach den Beobachtungen und Mitteilungen des Entdeckers beschrieben (erste Abtheilung, die Labroiden). Annln. wien. Mus. Naturg., 2: 1-470.
Linnaeus, C., 1758. Systema naturae per regna tria naturae, secundum classes, ordines, genera, species, cum characteribus, differentiis, synonymis, locis. Tomus I. Editio decima, reformata: 1-824 (L. Salvii, Holmiae).

Lowe-McConnell, R. H., 1964. The fishes of the Rupununi savanna district of British Guiana, South America. Part 1. Ecological groupings of fish species and effects of the seasonal cycle on the fish. J. Linn. Soc., (Zool.) 45 (304): 103-144.

NiJSSEN, H., 1967. Final remarks and tentative list of fish species. Progr. Rep. biol. Brokopondo Research Project, Surinam, 4: 240-246.

Norman, J. R., 1926. Descriptions of nine new freshwater fishes from French Guiana and Brazil. Ann. Mag. nat. Hist., (9) 18: 91-97.

Pellegrin, J., 1903. Description de Cichlidés nouveaux de la collection du Muséum. Bull. Mus. Hist. nat. Paris, 9: 120-125.

- - 1904. Contribution à l'étude anatomique, biologique et taxinomique des Poissons de la famille des Cichlidés. Mém. Soc. zool. France, 16: 41-402, pls. IV-VII.

-, 1905. Sur deux poissons du genre Crenicichla de la collection du Muséum de Paris. Bull. Soc. zool. France, 30: 167-169.

Perugia, A., 1897. Di alcuni pesci raccolti nell' alto Paraguay dal Cav. Guido Boggiani. Annali Mus. civ. Stor. nat. Genova, (2) 18 (2): 147-150.

PloEg, A., 1986. Occurrence and variability of Crenicichla saxatilis (Linnaeus, 1758) in Surinam, and restriction of its type-locality (Pisces, Perciformes, Cichlidae). Bijdr. Dierk., 56 (1): 47-59.

Puyo, J., 1949. Faune de l'empire français, 12. Poissons de la Guyane française: 1-280 (Office de la Recherche scientifique et technique d'Outre-mer, Paris).

Regan, C. T., 1905. A revision of the fishes of the South American cichlid genera Crenicara, Batrachops, and Crenicichla. Proc. zool. Soc. London, 1905: 152-168.

-, 1913. A synopsis of the cichlid fishes of the genus Crenicichla. Ann. Mag. nat. Hist., (8) 11: 498-504.

Richter, C. J. J. H. NiJssen, 1980. Notes on the fishery and fish fauna of the Brokopondo Reservoir (Surinam). Fish Mgmt., 11 (3): 119-130.

SteindaChNER, F., 1915. Ichthyologische Beiträge (XVIII). Sber. kaiserl. Akad. Wiss. Wien, math.naturw. K1., (1) 124 (8-10): 567-591.

Vaillant, L., 1900. Contribution à l'étude de la faune ichthyologique de la Guyane française et du contesté franco-brésilien. Nouv. Archs. Mus. Hist. nat., (4) 2: 123-135, pl. VII. 